\title{
THE FACTORS AFFECTING THE EXPORT POTENTIAL AND ITS FORMATION UNDER THE CONDITIONS OF INTEGRATION
}

\author{
Iryna LAVRIV 1 \\ Lviv National Agrarian University, Ukraine
}

\begin{abstract}
The aim of the article is to analyze the factors affecting the export capacity of the country and their interpretation by domestic and foreign scientists; to distinguish the basic classification and to form the unified system of factors that affect export potential of Ukrainian agricultural enterprises. On the basis of the classification of factors it is necessary to distinguish the main stages of development of the export opportunities of agrarian formations in the context of European integration. The method. Theoretical and methodological basis of the study is a critical analysis of the fundamental works devoted to the export potential increasing. The given tasks were solved on the basis of a systematic approach with using the scientific methods of analysis and synthesis. The method of abstraction was used in order to research the economic essence of the economic factors that impact the export potential of the company. The combination of the methods of analysis and synthesis were used to determine the priority directions of export opportunities development. The results of the research. The analysis of theoretical approaches to identify factors influencing the export potential of the enterprise is provided. This allowed identifying the several directions of classification. Results of the research helped to shape a common classification of factors that affect the export potential of agricultural enterprises and to distinguish the integration processes as a separate group of factors. On the basis of the classification of the main factors it was formed the phase of development of export opportunities in the context of approximation of the Ukrainian economy to the European standards. The prospects of development of the domestic agriculture export potential under the influence of international integration processes are grounded. They consist of the ability to increase the efficiency by redistribution of export volumes among major importers. The directions of activating the process of increase of efficiency of the basic agricultural branches export potential using by creating a positive image of agricultural enterprises and the directions of improving product competitiveness and quality standards of the European Union are determined. The recommendations for the ways of regulatory policy improvement at forming the legal provision of export potential in the context of European integration are developed (the selective support of structural changes in ways that exclude the possibility of using protectionist instruments by trading partners; creating the information system of foreign trade; expert and consultative support of export transactions). The practical meaning. The practical meaning of the results is the formation of the unified classification and grounding the factors which influence on the export potential of agricultural enterprises. The conclusions can be used in further improving the mechanism of foreign policy in Ukraine, in particular, in the process of the legal and regulatory framework improving, and in the process of assessing the prospects of the development of the international cooperation between Ukraine and foreign countries by Ukrainian ministries and special agencies. Significance/originality. The formed classification of factors will help to provide a better understanding of the export potential formation and can be used in management decisions by the leaders of farms in Ukraine and others countries.
\end{abstract}

Key words: export potential, agricultural enterprises, the factors of influence, the integration processes.

JEL Classification: P45, Q17

\section{Introduction}

The export potential of the enterprise as an economic category and an object of analysis got the increased attention of scientists and practitioners in the international business. The experience of highly developed countries and countries that are rapidly developing convinced that the dynamism of the positive development of most national economies largely achieved through an effective export policy, depending on the level of excellence of the processes associated with the formation and using of

\footnotetext{
Corresponding author:

${ }^{1}$ Department of the International Economics, Tourism and Foreign Economic Activity Management, Lviv National Agrarian University. E-mail: lavriv.im@gmail.com
} 
the export potential of both the state and entities, as well as the selection of methods and tools that can provide a successful course of these processes. However, despite the large number of domestic and foreign researchers, nowadays there is no unified classification of the factors affecting the export potential of agrarian business. The actuality of the topic is caused by the fact that under the conditions of unstable economic environment every subject of the foreign economic activity solves the problem of improving the efficiency of foreign trade operations. It is very important task to solve this problem under current economic environment. Thus, from the side of subjects of the economic activity the need to analyze the factors affecting the efficiency of foreign trade activities appears.

\section{The classification of the factors that affect the export potential of agricultural enterprises}

Analyzing the theoretical foundations and the essence of export potential, we concluded that the export potential is central element of the state economic growth. The overall development of the national economy and its monetary system, foreign trade balance and standard of living depend on the dynamics of exports. However, the export potential doesn't depend on the volume of exported goods, but on a huge number of factors, influenced on its formation. Exploring the impacts on export potential, it should be noted that a unified classification does not exist, but all factors, that scientists proposed, can be attributed to two main groups: internal and external (Figure 1).

The internal factors include the factors that influence at the formation of export potential of farm businesses of the company. Those factors A. O. Fatenok-Tkachuk divides into three groups: innovation and business activity of the enterprise, increasing the economic potential of the entity, support and stimulation enterprises with high export potential at the state level (Fatenok-Tkachuk, 2008). In his other work this author (Lipych \& FatenokTkachuk, 2010) in order to evaluate the impact of factors on the development of export potential of the company distinguishes the factors into two levels: micro and macro level.

On the micro level internal and external factors are distinguished. The internal factors caused by the enterprise' activity, and the external ones are the result of the public policy, the competitors activity, the environment in which the entity operates, so these factors have an impact on the state level, where the company operates. At the macro level there are factors that have an impact on the foreign competitors and the partner country. In addition, the external factors are separated to those caused by the activities of the state and those caused by the activity of the market player.

Olga Homenyuk attributes the factors related to the intra-corporate enterprises potential, which represents the ability to export development by using internal strengths and competitive factors of the company in order to gain the identified target export markets, to the internal factors External factors related to the external market export potential, which represents the ability to export development by finding new and developing existing target markets for export oriented products of the enterprise (using the external environment factors (Homenyuk, 2014).

As we can see the scientist includes to the factors two main elements: intra corporate environment and the sphere of foreign markets, but, in our view, external factors also include political, financial and legislative environment of the country in which the economic subject performs its financial and economic activity.

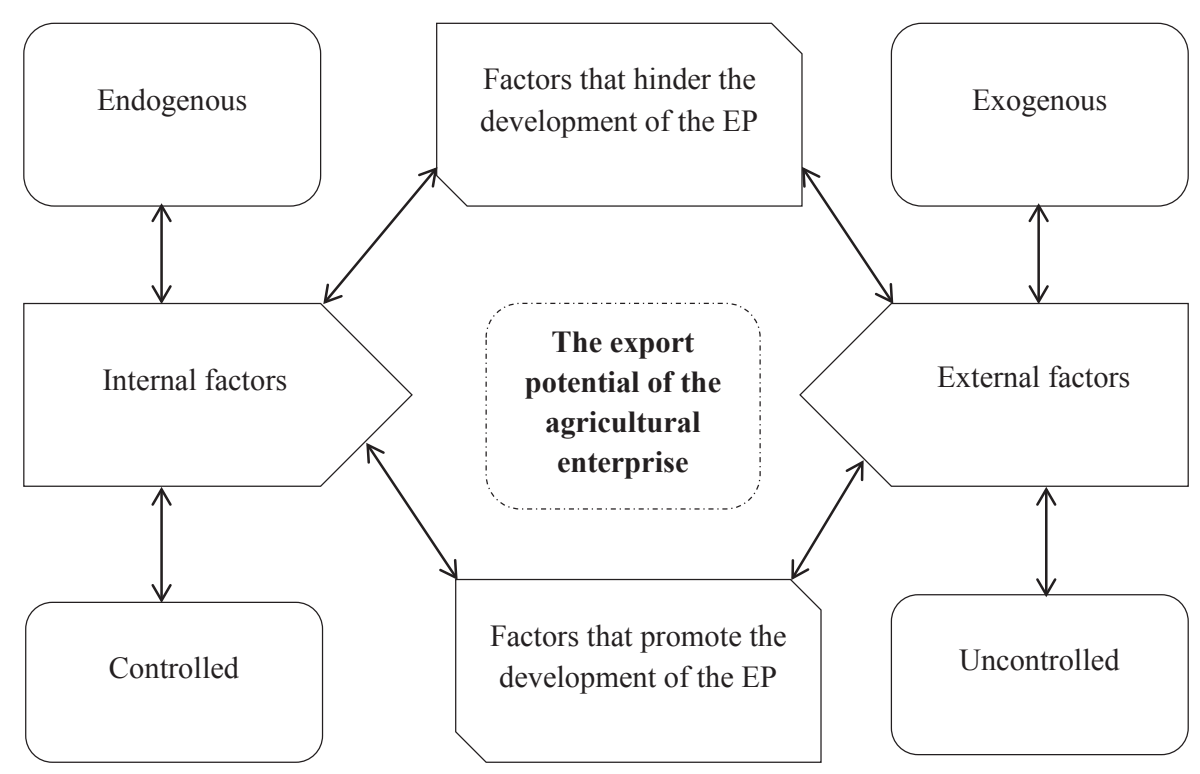

Fig. 1. The classification of the factors that affect the export potential of agricultural enterprises Source: it is summarized by the author on the base of the conducted research 
Belarusian scientists D. Formenok, S. Dubkov, S. Dadalko proposed a classification of the internal factors on the basis of the enterprise marketing environment and distinguished the several groups of the factors:

1) characteristics of the firm (size, international competence, the number of managers with international experience), product, industry and export market;

2) psychological characteristics and management advantages;

3) the choice of the target market and the segment

In order to analyze the factors influencing the export potential they are divided into:

1) controlled ones, which may vary in the right direction;

2) uncontrolled ones, which are divided into controllable and uncontrollable factors by state.

The scientists propose to distinguish two groups of factors depending on the degree of their control: endogenous - related with a company activity, its foreign marketing strategy, performance management; exogenous - include political, geographical, natural and environmental characteristics (Formenok, Dubkov, \& Dadalko, 2011).

Dunska A. R. considers that the most important internal factors of the export potential development include the following:

1) business management organization;

2) informational support of foreign economic activity;

3) export production planning;

4) accounting and analysis of export deliveries;

5) HR management (Dunska, 2013).

Baban T. O. exploring the export potential of barley as part of the external factors of barley export potential of the Ukrainian agricultural enterprises, which have the greatest influence under the modern terms, distinguished following factors:

1. Supply factors: natural resource potential in the producing countries; the overall development of agricultural production in producing countries; supply of the competing products; seasonality factor.

2. Demand factors: demographic factors; purchasing power in importing countries; geographical location; development and structure of livestock; consumption of competing cultures; the availability of information about the conditions of the Ukrainian barley sale.

3. Institutional factors: regulation of the barley trade by exporters, importers and the international organization.

4. Condition of infrastructure in exporting countries and importing countries (Baban, 2014).

The factors that hinder the development of innovative capacityincludeinfrastructuralproblemsandcharacteristics of business environment, energy inefficiency, complexity of the investment protection, insufficient development of the information and communication technologies, etc.

At the same time the factors, positively affecting the export activities of agricultural enterprises in Ukraine include the intensification of economic cooperation between Ukraine and the European Union. Our point of view also supports I. Sakalo. She thinks that the positive factors are the following:

- expansion of the cooperation areas between Ukraine and the EU;

- strengthening cooperation of both government and business partners;

- the implementation into practice the foundations of partnership and cooperation;

- removing obstacles (imperfections in the tax and judiciary, reducing corruption) due to integration processes;

- regular monitoring and evaluation of trade relations will be able to identify weak and strong areas, which in turn will strengthen the annual progress;

- reduction of trade barriers by changes in standardization, strengthening administrative control etc. (Sakalo).

The factors above contribute to the development of export potential related to environmental factors, scientist M. Nalyvayko identifies internal factors influence the development of export potential and considers that they include:

1. Improving the competitiveness of goods.

2. Reducing the cost of goods.

3. The increase the range of goods for various kinds of markets.

4. Development and implementation of export policy of the company.

5. Search and continuous analysis of new markets.

6. Searching for new and analysis of existing suppliers of materials and components for the production company.

7. Attracting foreign investment (Nalyvayko, 2015).

The author notes that the attraction of the foreign investment is the factor influencing the export potential. We share this point of view, because foreign investments play an important role in the present economic development of some countries and other economic crisis. The volume of foreign investments in the world is growing rapidly, thus increasing the role of the international production and international division of labor in the global economy. It is impossible to leave aside the impact of foreign investment in export activities of enterprises, because due to investments agricultural enterprises can update technical and technological base and increase product competitiveness.

Considering that the export potential of the country consists of the export potential of several parts of the economy L. P. Petrenko identifies three main elements that affect on its formation the most:

1) export competitiveness of the product;

2) export competitiveness of the manufacturer;

3) export competitiveness of a producing country (Petrenko, 2008).

Summarizing the above, it is worth noting that in Ukraine there are conditions for export potential development because strengthening and increasing the level of export potential of the agricultural enterprise is the primary factor of economic reforms, because the increase in export 
potential in agriculture is a significant source of foreign currency, which is necessary for social and economic development.

\section{Development of export potential in the context of European integration}

Development of export potential is associated with the integration processes taking place in the country. Nowadays the course of international economic integration is the engine of the world economies.

Integration as a process means measures aimed to eliminate the discrimination between economic units that apply to different states and integration, considered as a state which can be represented as a lack of various forms of discrimination between national economies. Thus, the disparities between countries development have to be negated in the process of integration. It means that in order to balance development it is necessary to complete the resource allocation. In order to avoid such unjust balance, the rational distribution of resources in terms of money or barter is required. We are more inclined to the opinion of $\mathrm{M}$. Arah, that the integration is the process of creating the optimal structure of the international economy and the smooth functioning of coordination mechanisms and unification (Arah, 1998) and support that it is the process of economic cooperation, which promotes the convergence of economic mechanisms.

The export of goods and services is one of the forms of economic cooperation, in our opinion. According to the economic essence these relate to economic integration, because as scientists (Hrontkovska, Riaba, Ventsuryk, \& Krasnovska, 2014) consider, the economic integration is a process of convergence, mutual adaptation and gradual integration of national economic systems. The others authors (Kozak, Lohvinova, Zakharchenko, \& Kravchenko, 2012) complement this point of view indicating that association of economies is intended for the free movement of goods, services, capital and labor across national borders.

Considering the factor of influence on export potential we mentioned external factors, including the isolated impact of foreign institutions. This impact is realized through the integration process. Summarizing the views of scientists, we have identified the main directions of Ukraine's integration into the world economy.

- Asian direction;

- Eastern direction (CIS);

- Western European direction (EU);

- African direction;

- American direction.

Considering the works of many scientists who conducted research of integration processes it can be argued that the most perspective way of Ukraine's entry into the global economy is «European integration.» N.V. Osadcha (Osadcha, 2011) gives the definition of the category «European integration» for Ukraine the most clearly. She notes that this is the way to modernize the economy, by attracting foreign investment and new technologies, increasing the competitiveness of

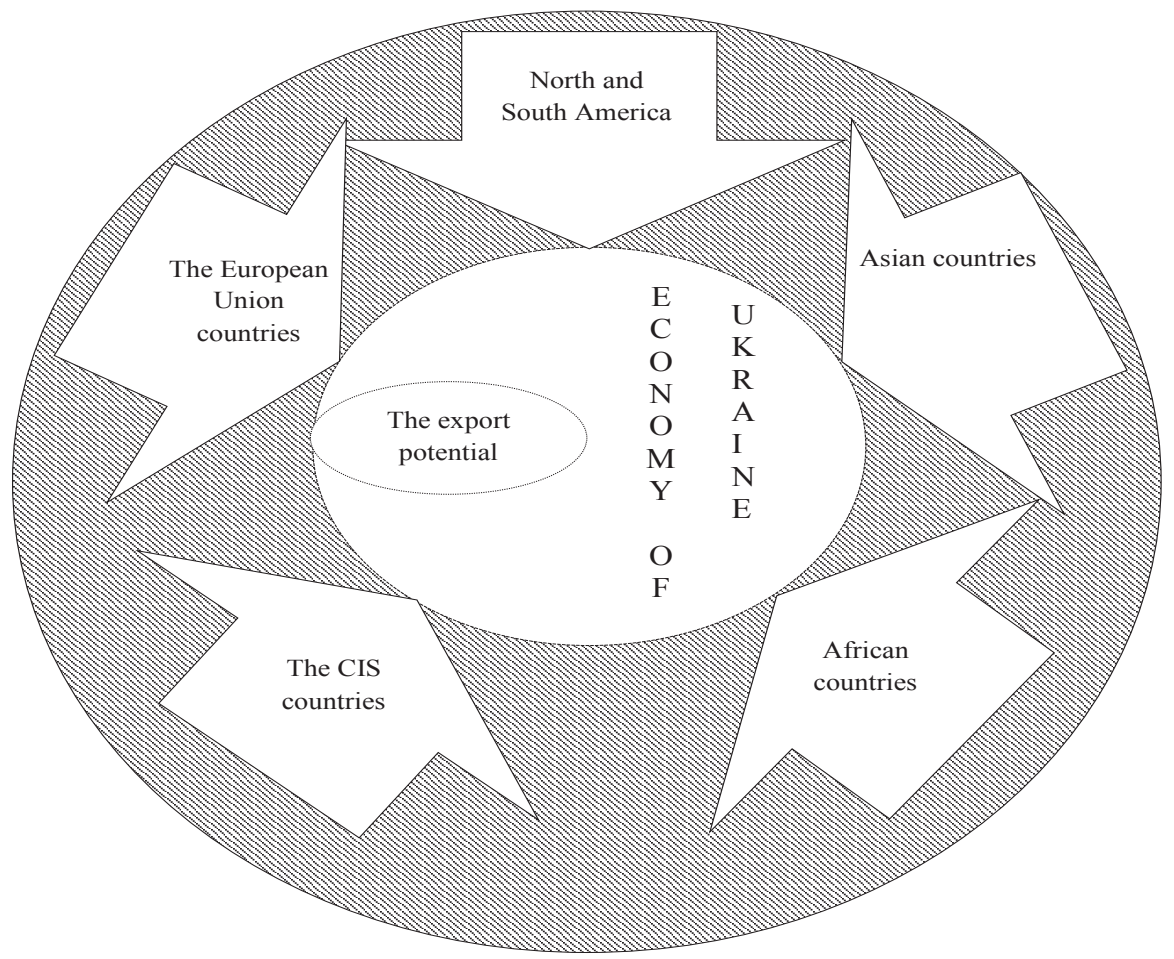

Fig. 2. The impact of integration processes on export potential

Source: the author's summarizing 
domestic producers, the possibility of entering the single EU internal market.

The final turn towards European integration took place after Revolution during 2013-2014 years. Ukraine became quickly reorient from the Russian market to European one. If in 2010-2013 the share of Russian exports from Ukraine was approximately equal to or a little higher than the share of the European Union, in 2014-2015, the share of the Russian Federation in Ukrainian exports has declined, while the share of the EU - has increased. Thus, in 2015 tendency to reduce the of Russian exports continued and the proportion in the general flow of merchandise exports for the first time was less than $15 \%$ (The unifiedcomprehensive strategy and action plan for the development of agriculture and rural areas in Ukraine in 2015-2020 years). Analyzing these figures we see that exports depends on the global integration process, that's why we consider that it is appropriate to reflect the impact of integration processes on the export potential of the company (Figure. 2).

While integrating into the world economy, countries make choices what direction of integration is beneficial for them in social and economic terms, and the lighter in the process of unification.

Extension of export potential in the context of European integration is an important aspect of improving the economic situation of the country, but according to the statistical information it is necessary to indicate the fact that exports of agricultural products in the European Union are insignificant. The reason is its low competitiveness, but as it was noted above, the outdated technical and technological base of agricultural enterprises effects on this. As the result, the production does not meet the requirements of the European market. Among the products that Ukraine exports to the EU cereal crops oilseeds, vegetable oil, waste food dominated, but the product line has prospects to expand and we suggest considering the main stages of increasing of export potential of agricultural enterprises at the national level and the impact of regulatory legal base that unsupports it (Figure 3).

Exit on foreign markets is impossible without a specific image of economic entity that depends on the quality of the products that it produces, on the ability to use modern methods of management, negotiations, and the established image of the country on the world economic scene. For Ukrainian agricultural enterprises the quality of production is an important factor of the image. The improvement of the quality of production is the next stage in the development of export potential. Only after produced products will correspond the quality standards, they can be removed from the territory of Ukraine.

\section{Conclusions}

The study identified and comprehensively researched the key factors influencing the development of the export potential of agricultural enterprises. Summarizing the research of domestic and foreign scientists it should be

1. Creating a positive image of agricultural enterprises

2. Improving the competitiveness of production

3. Compliance with the quality standards of the European Union

4. The analysis of the European market

5. Entering the EU market
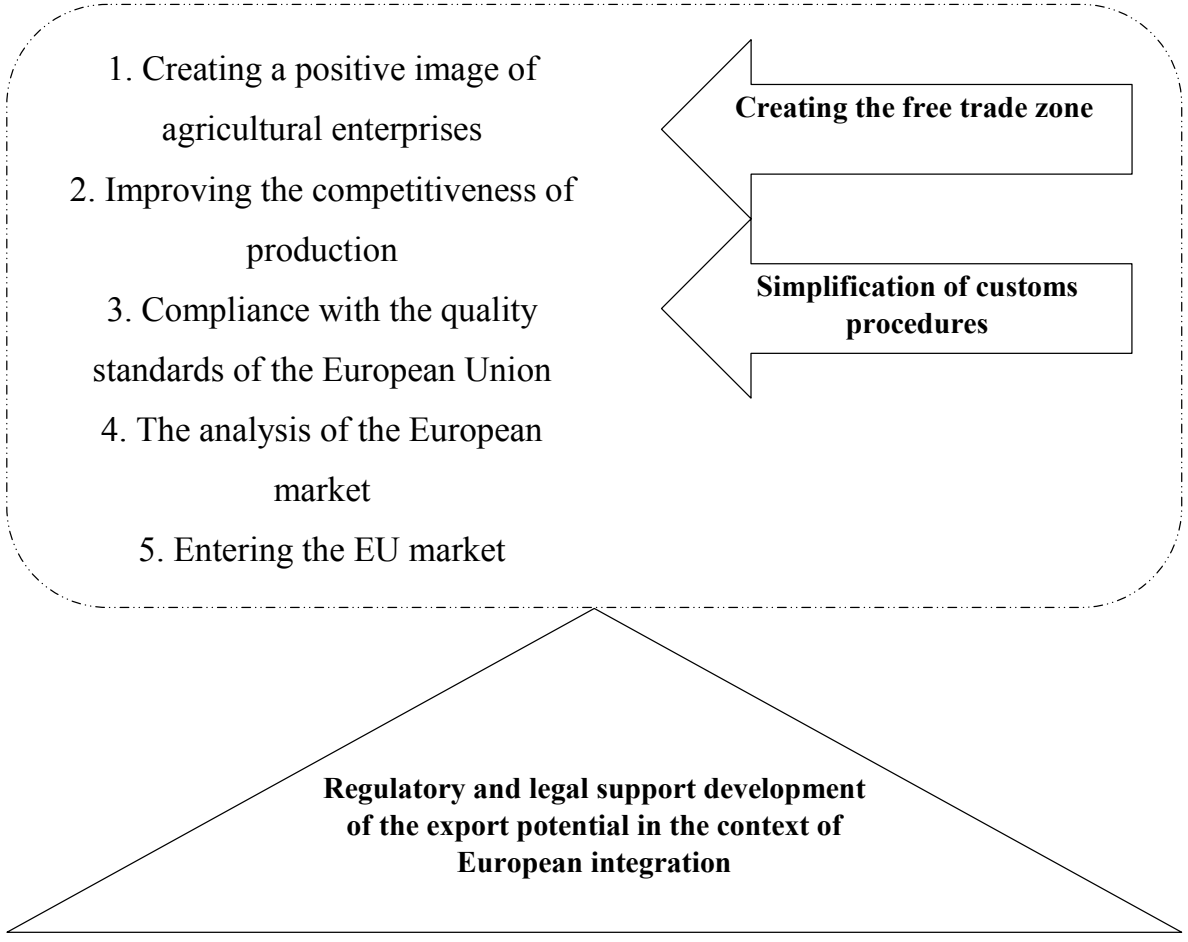

Fig. 3. The main stages of development of export potential of agricultural enterprises in the context of the processes of the European integration

Source: the author's summarizing 
noted that certain factors influence the export potential of the enterprise are systematic, because they form the export potential of the enterprise, and interdependent, because their meaning are combined by the single purpose - to ensure the development of foreign economic activity of the enterprise. The implementation of measures for each factor of development of export potential will improve the competitive position of the company and the effective promotion of enterprise in the target foreign market. Thus these factors affect not only the development of export potential, but in the final result they are able to enhance the competitiveness of the whole enterprise.

\section{References}

Arah, M. (1998). European Union: a vision of political unification. Moscow: The Economy.

Baban, T. O. (2014). External factors of the barley export potential. Bulletin of the Petro Vasylenko Kharkiv National Technical University of Agriculture (149), 73-80.

Homenyuk, O. (2014). Scientific achievements of young people - solving the problems of human nutrition in the XXI century: the program and materials of the 80 international scientific conference of young scientists and students. The theoretical basis of the grounding the export potential for food industry enterprises. 3, pp. $245-247$. Kyiv: NUXT.

Hrontkovska, Riaba, Ventsuryk, \& Krasnovska, (2014) International Economics (H. E. Hrontkovska, Edit.) Kyiv: Center of educational literature.

Dunska, A. R. (2013). The factors of the development of export potential of industrial enterprise. Efficient economy (3), 29-37.

The unified comprehensive strategy and action plan for the development of agriculture and rural areas in Ukraine in 2015-2020 years. (w.d.). Retrieved from: http://minagro.gov.ua/node/16025

Kozak, Lohvinova, Zakharchenko, \& Kravchenko (2012). International Economic Relations. Kyiv: Center of educational literature.

Lipych, L. H. \& Fatenok-Tkachuk, A. O. (2010). Forming a strategy of development of foreign engineering companies.Lutsk: the Lesya Ukrainka Volyn National University.

Nalyvayko, N. M. (2015). Scientific and practical Internet conference «Formation of potential of economic development of the industrial enterprises.» Extension ways of export potential of industrial enterprise (pp. 105-107). Odesa: ONPU.

Osadcha, N. V. (2011). Characteristics of the process of Ukraine's integration into the European Union (EU). The Economic Bulletin of Donbas (3(25)), 71-81.

Petrenko, L. P. (2008). The development of the export potential of the enterprise (on the base of materials of the milk processing enterprises). Abstract of the dissertation for a degree of Candidate of Economic Sciences : 08.00.04, 17. Kyiv: KNEU.

Sakalo, N. I. (without data). Estimation of expanding trade relations between Ukraine and the EU. Retrieved from: http://www.economy.nayka.com.ua/index.php?operation=1\&iid=1088

Fatenok-Tkachuk, A. O. (2008). Evaluation of the export potential of Ukrainian machine-building enterprises. The scientific bulletin of the Lesya Ukrainka Volyn National University, 7, pp. 72-79.

Fomenok, D., Dubkov S., \& Dadalko, S. (2011). Formation and an estimation of the export potential of industrial enterprises. The Bulletin of Bakov (10), 29-35.

\section{Ирина ЛАВРИВ}

\section{ФАКТОРЫ ВЛИЯНИЯ НА ЭКСПОРТНЫЙ ПОТЕНЦИАЛ И ЕГО ФОРМИРОВАНИЕ В УСЛОВИЯХ ИНТЕГРАЦИОННЫХ ПРОЦЕССОВ}

Аннотация. Целью работы является провести анализ факторов влияния на экспортные возможности страны и их толкование отечественными и зарубежными учеными; выделить основную классификацию и сформировать единую систему факторов, оказывающих влияние на экспортный потенциал сельскохозяйственных предприятий Украины. На основе классификации факторов выделить основные этапы развития экспортных возможностей аграрных формирований в контексте евроинтеграционных процессов. Методика. Теоретические и методологические основы исследования составляет критический анализ фундаментальных трудов по проблемам наращивания экспортного потенциала. Поставленные задачи решались на основе системного подхода с применением общенаучных методов анализа и синтеза. Метод научной абстракции использовался при исследовании сущности и экономической природы факторов, осуществляющим влияние на экспортный потенциал предприятия. Сочетание методов анализа и синтеза использовано для определения приоритетных направлений развития экспортных возможностей. Результаты исследования. Проведен анализ теоретических подходов к определению факторов влияния на экспортный потенциал предприятия, что позволило выделить несколько направлений их классификации. Результаты исследования помогли сформировать единую классификацию факторов, влияющих на 
экспортный потенциал аграрных предприятий и выделить интеграционные процессы, как отдельную группу факторов. На основе классификации факторов были сформированы основные фазы развития экспортных возможностей в контексте приближения украинской экономики к европейским стандартам. Обоснованы перспективы развития экспортного потенциала отечественного агропромышленного под влиянием международных интеграционных процессов, которые заключаются в возможности постепенного повышения уровня эффективности его реализации путем перераспределения объемов экспорта между основными импортерами; определены направления активизации процесса повышения эффективности использования экспортного потенциала базовых отраслей сельского хозяйства путем создания положительного имиджа аграрных предприятий, повышение конкурентоспособности продукции, соблюдения стандартов качества Европейского союза. Разработаны рекомендации по направлениям совершенствования регуляторной политики при формировании нормативно-правового обеспечения развития экспортного потенциала в контексте евроинтеграции (селективная поддержка структурных изменений в формах, исключающих возможность применения протекционистских инструментов торговыми партнерами, создание системы обеспечения внешнеторговой информации; экспертно-консультативное сопровождение экспортных операций). Практическое значение. Практическое значение полученных результатов заключается в формировании единой классификации и обосновании факторов влияния на экспортный потенциал сельскохозяйственных предприятий; его положения и выводы могут быть использованы в процессе дальнейшего совершенствования механизма внешнеторговой политики Украины, в частности, в совершенствовании ее нормативно-правовой базы, соответствующими министерствами и ведомствами при оценке перспектив развития внешнеэкономического сотрудничества Украины. Значимость/оригинальность Сложившаяся классификация факторов поможет обеспечить лучшее понимание формирования экспортного потенциала предприятия и может быть использована при принятии управленческих решений руководителями хозяйств Украины и других стран. 